Clemson University

TigerPrints

8-2016

Integration of Structural Health Monitoring and Intelligent Transportation Systems for Bridge Condition Assessment: Current Status and Future Direction

Sakib Mahmud Khan

Sez Atamturktur

Mashrur Chowdhury

Mizanur Rahman

Follow this and additional works at: https://tigerprints.clemson.edu/elec_comp_pubs

Part of the Civil and Environmental Engineering Commons 


\title{
Integration of Structural Health Monitoring and Intelligent Transportation Systems for Bridge Condition Assessment: Current Status and Future Direction
}

\author{
Sakib Mahmud Khan, Sez Atamturktur, Mashrur Chowdhury, Senior Member, IEEE, and Mizanur Rahman
}

\begin{abstract}
Recent catastrophic bridge failure clearly indicates the urgent need of improving interval-based bridge inspection procedures that are qualitative and subjective in nature. Structural Health Monitoring (SHM) can mitigate the deficiencies of interval-based inspection techniques, and provide real-time diagnostic information regarding the bridge structural health. SHM is not flawless however; the variability in the vehicle characteristics and traffic operational conditions makes it prone to false-diagnosis. Recent advancements in the integration of SHM with Intelligent Transportation Systems (ITS) demonstrate the successful use of ITS devices (e.g., machine vision, traffic sensors) in the analysis of bridge responses to multi-modal traffic with varying loads or during the critical events (i.e., excess vibration beyond normal limit). In ITS-informed SHM system, the ITS device collected data can be integrated with SHM to increase the reliability and accuracy of the SHM system. This integration would reduce the possibility of false diagnosis of the SHM system (such as vibrations caused by heavy vehicles on a bridge could be read by a SHM sensor as a structural health problem of the bridge), which would eventually decrease the bridge maintenance costs. Similarly in SHM-informed ITS system, SHM sensor data can provide data on bridge health condition for ITS applications, where ITS uses this bridge health condition information for real-time traffic management. In this paper, literature related to both ITS-informed SHM and SHMinformed ITS is reviewed. Based on the literature review, potential challenges and future research directions associated with ITS-SHM integration are also discussed.
\end{abstract}

Index Terms - Bridge condition assessment, Condition-based monitoring techniques, Integrated SHM-ITS, Intelligent transportation system.

\section{INTRODUCTION}

$\mathrm{I}_{\mathrm{M}}^{\mathrm{N}}$ August 2007, the I-35W Bridge in Minneapolis, Minnesota, US, collapsed due to the insufficient load carrying capacity of its structural components, which raised significant concerns about the nation's bridge inspection and maintenance procedures [1]. As a result, a focused effort was begun to evaluate practices and procedures utilized in bridge inspection and maintenance. Five safety issues were identified in a study conducted by the National Transportation Safety Board (NTSB), two of which detailed the lack of inspection guidance and the improper use of resources to accurately determine the structural condition of bridges [2]. Important considerations for reliable bridge inspection to improve traveler safety have been highlighted in the NTSB report [3].

Manuscript received February 21, 2015.

S.M. Khan, S. Atamturktur, M. Chowdhury and M. Rahman are with the Glenn Department of Civil Engineering, Clemson University, Clemson, SC 29634 USA (e-mail: sakibm@g.clemson.edu, sez@clemson.edu, mac@clemson.edu,mdr@clemson.edu).
There are two basic types of bridge inspection techniques currently used: 1) the interval-based inspection technique and 2) the condition-based inspection technique. Interval-based inspection is the most common one, and has long been in use to evaluate the condition of bridges. The minimum requirements of interval-based inspection techniques are mentioned in the National Bridge Inspection Standards or NBIS [4], in which site visits are performed at a predetermined frequency, such as once in every two years for routine inspection of bridges [2]. Only when the bridge is at high risk of catastrophic failure, interim bridge inspection is performed. Currently, the NBIS only requires that bridges undergo interval-based inspection. There are two types of interval-based inspection techniques available: 1) the routine visual inspection technique and 2) the non-destructive inspection (NDI) technique. Among them, the most common type of inspection required by the NBIS is routine visual inspection by a knowledgeable and experienced inspector. Unfortunately, the results from such inspections often vary greatly [5]. NDI, another interval-based inspection technique, can identify and determine bridge damage without causing any further damage to the structure. Acoustic sounding, chain drag, ultra-sonic testing, impact echo, and reflected radar wave methods are but a few of the commonly used NDI inspection methods [6]-[10]. While the interval-based inspection techniques are typically, their accuracy is hindered by the requirement of an inspector's interpretation, the method's dependency on the test conditions, and the inaccessibility to the area of damage. The applicability of non-destructive tests may be limited due to the scatter in data resulting from the spatial variability of the bridge material [11], and substantial time and resources requirement for such tests [12].

The restoration of aged and decaying infrastructures is identified as one of the greatest challenges for the United States in the American Society of Civil Engineers (ASCE) report [13], [14]. The substantial increase in the prevalence of these aged infrastructure and the limited resources available for their repair necessitates an urgent need to increase the effectiveness and efficiency of the interval-based technique. This has resulted in the development of a second, but still emerging technique: condition-based inspection. Conditionbased inspection entails the near continuous monitoring of selected response features of a bridge (e.g. vibration responses, operational deflection shape, strain measurement). If any observed values of these features crosses a certain threshold, maintenance is requested. This condition-based inspection technique, which the engineering community recognizes as Structural Health Monitoring or SHM, is used to identify the damage and determine the damage extent as it occurs in real time, which mitigates the risk of damage going undetected between interval-based inspections while lowering 
inspection costs [15]. However, SHM-enabled inspection may yield false diagnosis due to the variability in vehicle characteristics under which the bridge functions [16], [17]. An integrated ITS-SHM framework can mitigate these false diagnoses.

SHM is an emerging and innovative structural condition assessment technique, which has been used in both developed and developing countries to monitor the behavior of critical infrastructures (e.g. historic architectures, high-rise buildings) and to assess the structural performance of bridges under various service loads [18]. Using data generated from SHM sensors, an automated warning system can disseminate realtime pavement conditions during periods of severe weather condition (i.e., heavy rain, snow, high temperatures) [19]. High ambient temperatures may cause unexpected expansions in the highway bridge pavement, which may cause an expansion failure. Extreme temperatures cause SHM sensors installed at critical bridge components trigger alerts, which can be used to impose restrictions or divert traffic to other routes. The Alaska Department of Transportation uses such a system to adjust seasonal load restrictions by measuring the temperature at various pavement layers [20]. Similar to SHM, ITS is a rapidly expanding realm of research, in terms of coverage and functionality, with its applications on freeway traffic operations including incident management and traffic control [21], real-time traffic condition assessment [22], and travel time prediction using traffic measurements [23] etc. Travel time prediction is required for traffic operation management in case of sudden incidents or ongoing bridge maintenance work. In addition, developing countries are using ITS for traffic surveillance and advisory operations [24]. It is plausible to believe that the combined ITS-SHM will replace interval-based techniques currently in use. ITS could be implemented through the integration of different components that includes multiple traffic monitoring sensors, instrumented probe vehicles, traffic management centers (TMCs). Continuous improvements in communication system and sensor technology are now making it possible to integrate both SHM and ITS. The integrated use of SHM and ITS system can provide a unique opportunity to leverage these two already in place system, and to maximize the effectiveness of both systems. This integration can also significantly reduce the cost compared to the implementation of stand-alone SHM and ITS systems [25].

The objectives of this research are to review literature on the integrated ITS-SHM system, and to identify challenges and provide future research directions for proper SHM-ITS integration. In Section II of this paper, the steps associated with SHM (i.e., condition-based inspection method) are discussed, followed by a summary of the limitation of SHM in Section III. In Section IV, literatures where ITS is used to improve the reliability of SHM diagnosis (i.e., ITS-informed SHM) is detailed. In Section V, discussion on the earlier research, where SHM sensors are used for gathering information to help ITS (i.e., SHM-informed ITS), is included. The challenges and future research direction of both ITSinformed SHM and SHM-informed ITS systems are discussed in Section VI.

\section{Structural Health Monitoring Technique}

Historically, non-continuous or interval-based inspection methods have long been in use to evaluate the condition of bridges. There has been a recent noticeable transition from traditional preventive maintenance to SHM for in-service bridges [26]. Herein, the authors confine the discussion to SHM (i.e., condition-based inspection method). SHM entails the near continuous and autonomous monitoring of selected damage sensitive response features of a structure of interest through a sensor network system. SHM links the observed changes in these response features to the onset of structural damage. This new approach for inspection allows bridge owners to make pertinent maintenance decisions based on the condition of the structure without relying on a human inspector to assess the bridge condition and to interpret the data, offers low cost operation, and suggests a reliable approach to assess the infrastructure condition in inaccessible regions [27], [28]. Many SHM systems involving both wired and wireless sensor networks have been developed over the last two decades [29], [30]. If the near-continuous structural data acquisition and processing steps of SHM can be combined with the visual inspection technique (i.e., an interval-based inspection technique), early identification of bridge health problems can be enabled with minimum human error from standalone visual inspection technique [31].

In the context of standalone SHM, damage refers to the material, connectivity and/or changes in the structural geometry that adversely affects the structural performance. These changes include, but are not limited to material deterioration, the accumulated effects of aging, the changes in boundary condition and the loss of connectivity within the structural components. The concept of damage identification is a five step process [32].

Step 1: Detection of the damage area

Step 2: Localization of damage

Step 3: Classification of the damage type

Step 4: Quantification of the damage extent

Step 5: Prognosis or estimation of the structure's remaining life

A complete SHM system has four distinct steps [33]. These steps are summarized as follows:

\section{1) Operational evaluation}

The purpose of an operational evaluation is to gather as much prior information as possible on the structure to investigate the feasibility of implementing the SHM system. The four criteria commonly determined during such operational evaluations are:

a) The type and severity of damage;

b) The operational and environmental conditions of the road/bridge;

c) The restrictions on data collection due to the operational and environmental conditions; and

d) The economic and/or safety feasibility of implementing an SHM system.

2) Data acquisition and cleansing

The ability to obtain accurate measurements of the structural characteristics is vital to the success of a SHM system. One of the key aspects of obtaining accurate measurements is the selection and placement of the sensors. 
The bridge vibration and deflection can be measured with a laser doppler vibrometer installed in the bridges [34]. Another emerging approach is the use of digital cameras to quantify bridge deflection under dead and moving loads, and to identify and quantify structural damage [35]. The Train Intelligent Monitoring System is also now available to detect irregularities in railway tracks by observing the vibration responses, as is the Vehicle Intelligent Monitoring System, to collect road data via a vehicle mounted Global Positioning System (GPS) sensor and an accelerometer, and a portable computer to monitor the condition of highway pavement and expansion joints [36]. In each of these systems, the desired data is collected and stored in the data acquisition stage, and transmitted in an automated manner in real-time to facilitate continuous and remote monitoring of the structure. In the data cleansing process, the accuracy and reliability of the collected data are evaluated and decision is made to forward the data to the feature extraction process [37]. Data cleansing is used to eliminate data that has become corrupted or unreliable during the data acquisition process.

\section{3) Feature extraction}

Feature extraction involves extracting low-dimensional feature vector from the measured field data that are sensitive to changes in the structural condition of a system. A comparison of these features makes it possible to differentiate between the damaged and undamaged structural states [33]. Selected features should ideally be insusceptible to ambient noise, sensitive to structural damage and computable in a timely manner [38]. Features with a low dimensionality are preferable since they allow for statistical evaluation of the trends in the collected data in a more straightforward manner. The features that have an intuitive, physical meaning allow easy communication between involved parties and features that reflect the nature of the structural response, i.e. linear versus nonlinear responses tend to be effective in indicating changes in the system behavior.

The most widely used features to identify, locate, classify and quantify structural damage are those that are based upon vibration responses, including natural frequency [39], [40], mode shape [41], [42], operational deflection shape [43], [44], modal strain energy [45], residual force vector [46], and frequency response [47]. Moreover, ITS applications also have features useful for SHM. For example, the features used by the video camera monitoring system are the coordinates of reference points to find in-plane displacements and rotations [48], operational deflected shapes [49], and locations of vehicles that can be used to devise an index called the unit influence line [50]. Fiber optic sensors use features such as displacement [51], strain and temperature [52], acceleration and inclination [53].

\section{4) Statistical model development}

The purpose of a statistical model is to identify changes and trends in the response of a structure. Statistical models to detect changes in bridge behavior are the algorithms that use the damage sensitive features extracted in the previous step (Step 3) to appraise the structure's condition [37]. The algorithms of statistical model development are classified as either supervised or unsupervised learning algorithms. In a supervised learning algorithm, data is collected from the damaged and undamaged condition of the structure. If data is obtained from only the undamaged condition, the algorithm is classified as an unsupervised learning algorithm. Common statistical models include a) Moving Average (MA), b) Auto Regressive (AR), and c) Auto-Regressive-Moving Average (ARMA) models [47]. The algorithms used in this stage are broadly categorized as data based algorithms (i.e., algorithms that rely on the measured data) and model based algorithms (i.e., algorithms which integrate measurements with a numerical model developed based on physics principles) [5456].

\section{LIMITATION OF EXISTING SHM TECHNIQUE}

For SHM to replace conventional interval-based assessment techniques, further research is needed to enhance its practical applicability. Bridge vibration characteristics (i.e., natural frequency and damping) are influenced by the speed and mass of the moving vehicles as they alter the effective mass of the bridge. In their study on a long plate girder bridge, Kim et al., concluded that the presence of heavy traffic decreased the natural frequencies by $5.4 \%$, unlike the study of Farrar et al., which determined a 5\% variability in frequency in a 24 hour time period [40], [57]. This level of variability can cause two problems in damage diagnostics: it may either mask the onset of damage (false negative) or it may interpret the changes in the data from the traffic as damage (false positive). Moreover, the variations in both the mass of the vehicles on the bridge and the traffic-induced excitations can alter the time history vibration response of a bridge, which in turn affects both the central tendency of the measured response data and excitation levels. Therefore, statistical modeling methods, which do not consider variations in traffic operational condition (e.g., traffic speed, vehicle position) or vehicle characteristics (e.g., vehicle size, loading) are prone to making false diagnosis. Previous researchers, for instance, Farrar and Jauregui did not consider traffic loading while comparing damage detection algorithms for a bridge structure [58]. Lee et al. presented an artificial neural network-based bridge damage assessment framework that uses the ambient vibration data induced by traffic [59]. However, in standalone SHM system, there still remains a gap in statistical modeling for not considering traffic speed, vehicle location, and other traffic parameters that influence the bridge structural vibrations. These limitations can be overcome by improving the knowledge of operational conditions of bridges through ITS [60]. Determining this traffic-induced mass loading and ambient excitation is necessary for normalizing the measured vibration response data [61]. The inclusion of dynamic traffic characteristics (e.g., traffic speed, volume) and vehicle loading information into the statistical damage detection algorithms can yield significant improvements in diagnostic evaluation accuracy.

The proper integration of ITS and SHM system can yield a mutually beneficial relationship. Real-time traffic data collected by ITS devices can be fed into the SHM system, which will increase the reliability of bridge health condition diagnosis. The structural state of the bridge identified by SHM can in turn be communicated to TMCs. Recent research incorporating the occurrence of SHM and ITS is discussed in Section IV and V. 


\section{ITS-INFORMED SHM}

In an ITS-informed SHM system, the integration of data collected through the ITS devices and SHM sensors in turn improve the reliability of SHM. ITS devices include roadway traffic monitoring sensors, such as loop detectors, weigh-inmotion station (WIMS), digital traffic monitoring camera etc. By integrating the collected traffic information with a SHM system, the effect of traffic operational condition on the bridge structure can be evaluated [61]. Different study of ITSinformed SHM system have been reviewed in the following subsections.

\section{A. ITS-informed Bridge Response Study for Regular Traffic Flow}

ITS has been used to investigate bridge behaviors under normal traffic flow. Zaurin and Catbas used data collected from both ITS and SHM sensors, and synchronized the data to construct Unit Influence Lines (UIL). UILs are considered as the index to monitor the bridge behavior under particular loading conditions [63]. At any given point on a structure, UIL shows the response variation caused by a moving unit load. ITS devices (i.e., video cameras) were used to identify, classify, and locate vehicles on the bridge. UIL was obtained based on the responses from SHM sensor (i.e., strain gauge, accelerometer) corresponding to the movement of the vehicles across the bridge surface. The UIL obtained using the predetermined vehicle positions were then compared to the UIL obtained by the integrated ITS-SHM system. Results from the study show an agreement between the UIL obtained from the integrated system and those obtained from the predetermined load locations. After developing the UIL, Zaurin and Catbus used it to identify the critical load combination effects on the bridge for predicting the bridge behavior under those load combinations. Their findings are promising concerning the use of ITS-informed SHM system to accurately diagnose bridge health.

In a similar study on the Sunrise Bridge, in Fort Lauderdale, Florida, Catbus et al. incorporated traditional SHM sensor (i.e., strain gauge) with ITS device (i.e., video camera) to create an effective structural monitoring tool under unknown loading conditions [64]. Here, Catbas et al. used a computer vision process to analyze the images to understand the image content (i.e., vehicle types, vehicle locations). Using data derived from the strain gauge and video camera, the authors experimentally performed the load rating analysis to calculate the bridge structure's load carrying capacity. The extracted UIL from the SHM sensor and the synchronized image measurement were used to calculate the bridge rating. In this experiment, the authors compared the load rating results with a finite-element model and validated the result. It is observed that for empty trucks, the variation of the load rating data from the proposed method is only $0.48 \%$ when compared with the finite-element model, thus it highly correlates.

To determine the level of traffic needed to induce bridge excitement, a stochastic model was developed by Chen et al. [65]. Authors assumed that the traversing vehicles can be represented as the sequence of Poisson processes moving load, where considering the movement of the load as a stochastic process, shifting load and time points of the load advancement are counted. In this experiment, noises due to traffic operational variation were accommodated by extending the excitation model. The authors videotaped moving vehicles and synchronized that movement with the data recordings from an accelerometer. Later, each vehicle speed was derived from the time difference between two timestamps attached with the entering and exiting frames of the camcorder recorder. Moreover, the authors measured the covariance between equivalent nodal forces at various node points. It is found that the covariance between any node pair is a non-zero function, and thus, the bridge traffic excitation is spatially correlated. Such spatial correlation is not observed in bridges, which carry two-way traffic. In order to monitor the change in bridge behavior due to traffic-induced vibration, the Cut River Bridge is instrumented by the Michigan Department of Transportation with different contact sensors and traffic monitoring devices [66]. The traffic data collected from wireless weigh-in motion station are verified with the video cameras. The archived data can be used to correlate and compare the actual bridge service loads and the loads which are used as design load.

\section{B. ITS-informed Bridge Response Study for Critical Events}

Bridge critical events entail special types of events where bridges experience vibration beyond the normal limit. In this regard, Fu and Moosa presented a method to diagnose the condition of the bridge structures with the help of highresolution images provided by a camera [67]. According to the authors, use of camera offers a cost-effective solution to diagnose whole bridge structure. Using accelerometers placed on a bridge to determine such vibrations is also possible, but it is more expensive in that such analysis requires many accelerometers compared to camera. Also, no technique is available to diagnose whole structure using the measurements from only few accelerometers. Authors demonstrated their research in the laboratory. With the help of camera, they detected structural damages causing as low as 3\% loss in the stiffness of the structure. Result from the study shows that high-resolution cameras can be used to clearly recognize the structural damage and identify location of the damages. One of advantages of the camera used in their study is that it can be redirected to critical events. Basharat et al. used this particular function of the camera for studying network traffic activity from a remote location (i.e. a remote observatory) in their research [68]. As the activity metric value, Basharat et al. used the mean shift vector in this research, which is compared against the threshold value. When the value of the activity metric is lower the threshold value, it indicates that the vibration occurs due to normal traffic and the data should not be considered as an event. When the vibration levels exceeded the established threshold value, the base station was notified and the camera was directed towards the point of interest, and panned, tilted or zoomed to the event using the information gathered.

An integrated SHM-ITS system is also effective in identifying the damage caused by overweight vehicles. Loh et al. synchronized the video streaming data from a high resolution camera (i.e., ITS device) with the data collected by wireless accelerometer sensor (i.e., SHM sensor) to trace the cause of damage from specific vehicles, such as an overweight truck or trailer on the Voigt Bridge, California [69]. In this 
study, the acceleration response and the operational deflected shapes due to the loads from vehicles passing over the bridge were measured using the wireless SHM sensor network. Results from this study show that correlating the video camera data with the recorded acceleration time histories obtained from wireless sensors can identify a vehicle's influence on the bridge response. After identifying vehicle-induced vibration, false diagnosis by SHM sensors can be identified, which would in turn reduce the bridge maintenance costs.

\section{ITS-informed Complete Bridge Management System}

It is important to establish a bridge management system that consists of the following four components: information acquisition, data management, evaluation and decisionmaking, and application service. Chen et al. conducted a study that combines SHM and ITS for intelligent management of Zhijiang Bridge in Hangzhou City, China [70]. Vehicle characteristic data (i.e., vehicle load) along with bridge health monitoring data (i.e., strain, deflection, vibration) were collected to assess bridge health condition. An ITS device (i.e., weigh in-motion station with a video capture function) was used to capture vehicle weight and to obtain the license plate numbers of overweight vehicles. The core of the intelligent bridge management system is the structural status evaluation subsystem, which uses the data collected by different SHM and ITS sensors. The data processing module and the status evaluation module are the two modules of this status evaluation subsystem. The data processing module conducts statistical analysis using data from each sensor. The status evaluation module localizes, quantifies, and identifies damage by monitoring trends of structural response and evaluates the bridge health status. In this study, Chen et al. used ITS-informed SHM system to generate time-specific status information, which provides data support for bridge maintenance and decision making. By providing reliable data for bridge maintenance and decision making, this ITSinformed SHM system eventually reduced the maintenance cost of the structure. The problem of managing large amounts of multi-parameter traffic data has also been addressed by Glisic et al. [71], who developed a software package that gives users real-time access to both present and historic data. The developed software has three main components: (1) software linked with the SHM system to acquire data, (2) live portal software that allows remote visualization of live traffic data in real-time and (3) playback software that helps users to visualize and interpret historic data.

Integration of SHM with the traffic monitoring system poses a data analytics problem. In 2011, Vespier et al. conducted a study on the large Hollandse Brug Bridge in Netherlands that successfully linked the real time traffic data with SHM [72]. The bridge was instrumented with 145 sensors and a camera is used to record the traffic to continuously record time-specific data. The authors used Hadoop data analytics framework to manage the large quantity of data using a cluster of 5 quad-core computing nodes.

The review of recent studies focusing on ITS-informed SHM suggests that ITS devices can help to locate the exact source of bridge excitation and to verify critical events, thus it can mitigate the potential false-diagnosis of standalone SHM systems due to variable traffic excitation. Within very short time intervals, ITS device incorporated data management systems can process an enormous amount of data that has been generated continuously from the traffic movement. Table I presents the main aspect of the research on ITS-informed SHM, devices used, strategies followed, research outcomes, the advantages and limitations of each as well as the type of the project.

\section{SHM-INFORMED ITS}

A study by the Texas Transportation Institute revealed that for the year 2007, congestion costs for US urban travelers was $\$ 78$ billion from 4.2 billion extra hours on the road and 2.9 billion gallons of fuel during congestion [73]. According to the Federal Highway Administration (FHWA), nonrecurring congestion causes about half of the total congestion. Non-recurring congestion is the temporary disruption of normal traffic flow which includes congestion due to incidents, temporary bridge shut-down and/or emergency bridge maintenance work. Real-time information regarding bridge health conditions provided by SHM can help ITS improve traffic management during bridge maintenance work on the bridge. ITS can inform and/or reroute traffic, in realtime, before a shutdown occurs due to emergency bridge maintenance work or during/after natural disasters and restrict overweight vehicles. Real-time traffic rerouting is a critical component of incident management through ITS to minimize traffic delays and reduce the probability of secondary incidents [74], [75]. Receiving early notification regarding the bridge health, significant traffic diversions from the route towards the bridge can take place using ITS devices (e.g., variable message signs), which could reallocate traffic volumes across the network and minimize the impact of nonrecurring congestion [76]. In SHM-informed ITS system, data collected by SHM sensors for a bridge can be integrated with existing ITS services. Here, based on the structural conditions of a given bridge, real-time traffic management decision can be made to minimize safety risks and traffic congestion potentials at the bridge. Related literature where SHM is successfully integrated with ITS is discussed in the following subsections.

\section{A. SHM-informed ITS to Determine Traffic Operational Condition}

SHM systems can help ensure the smooth and safe flow of the traffic stream by providing necessary information required by different ITS applications to determine traffic operational condition (i.e., macroscopic traffic information such as traffic volume, density). Sun and Sun incorporated the structural response monitoring sensors (i.e., strain sensor, accelerometer) with ITS devices (i.e., video camera, inductive loop) to measure traffic volume, traffic density, vehicle speed, vehicle space and many other traffic flow parameters [60]. From their analysis on strain-history, they found that moving vehicles directly contribute to the main girder vibration. As the video monitoring system is unable to determine the axle load and axle spacing, the weight measuring devices (e.g. the weigh-in motion and inductive loop technologies) were used to mitigate 
TABLE I

STUDIES ON ITS-INFORMED SHM

\begin{tabular}{|c|c|c|c|c|c|c|c|c|}
\hline $\begin{array}{l}\text { Key } \\
\text { feature }\end{array}$ & $\begin{array}{c}\text { Main aspect of the } \\
\text { research }\end{array}$ & $\begin{array}{c}\text { Devices/ } \\
\text { Sensors/Station }\end{array}$ & Strategies & $\begin{array}{c}\text { Issues investigated in } \\
\text { the research }\end{array}$ & Advantages & Limitations & $\begin{array}{c}\text { Type of } \\
\text { project }\end{array}$ & Source \\
\hline \multirow{3}{*}{$\begin{array}{l}\text { ITS- } \\
\text { informed } \\
\text { bridge } \\
\text { response } \\
\text { study for } \\
\text { regular } \\
\text { traffic flow }\end{array}$} & $\begin{array}{l}\text { Analyzed and } \\
\text { synchronized } \\
\text { sensor data with } \\
\text { video image to } \\
\text { create a UIL as } \\
\text { the index to } \\
\text { monitor bridge } \\
\text { behavior }\end{array}$ & $\begin{array}{l}\text { - Video camera } \\
\text { placed in the } \\
\text { direction of traffic } \\
\text { flow } \\
\text { - Sensors (strain } \\
\text { gauge }^{1,2} \text { and } \\
\text { accelerometer }{ }^{1} \text { ) } \\
\text { connected to the } \\
\text { bridge }\end{array}$ & $\begin{array}{l}\text { Video processing and } \\
\text { computer vision } \\
\text { algorithms }\end{array}$ & $\begin{array}{l}\text { Development of UIL } \\
\text { from the responses of } \\
\text { vehicle as an index in } \\
\text { order to monitor } \\
\text { behavior of bridge for } \\
\text { identified }{ }^{1} \text { and } \\
\text { unknown }{ }^{2} \text { loading } \\
\text { conditions }\end{array}$ & $\begin{array}{l}\text { Study of UIL can track } \\
\text { the structure } \\
\text { deterioration with time }\end{array}$ & $\begin{array}{l}\text { Synchronizing time } \\
\text { with distance, data } \\
\text { filtering, } \\
\text { environmental issues } \\
\text { etc. causes } \\
\text { uncertainties in using } \\
\text { the UIL as a health } \\
\text { condition monitoring } \\
\text { index }\end{array}$ & $\begin{array}{l}\text { Experimental } \\
\text { study }\end{array}$ & $\begin{array}{l}\text { Zaurin and } \\
\text { Catbas }{ }^{1} \\
\text { [63] } \\
\text { Catbus et } \\
\text { al. }{ }^{2}[64]\end{array}$ \\
\hline & $\begin{array}{l}\text { Synchronized } \\
\text { images of passing } \\
\text { vehicles to } \\
\text { develop traffic } \\
\text { excitation model }\end{array}$ & $\begin{array}{l}\text { - Accelerometer fitted } \\
\text { with the bridge } \\
\text { - Digital traffic } \\
\text { camera }\end{array}$ & $\begin{array}{l}\text { Image processing } \\
\text { algorithm (for } \\
\text { vehicles' speed } \\
\text { calculation) }\end{array}$ & $\begin{array}{l}\text { Stochastic model } \\
\text { development for } \\
\text { vehicle excitation on } \\
\text { bridge structure }\end{array}$ & $\begin{array}{l}\text { - Traffic camera does } \\
\text { not interrupt the traffic } \\
\text { flow } \\
\text { - Data can be collected } \\
\text { continuously }\end{array}$ & $\begin{array}{l}\text { Image capturing } \\
\text { performance of } \\
\text { camera can be } \\
\text { hindered by } \\
\text { environmental } \\
\text { conditions } \\
\end{array}$ & $\begin{array}{l}\text { Experimental } \\
\text { study }\end{array}$ & $\begin{array}{l}\text { Chen et } \\
\text { al.[65] }\end{array}$ \\
\hline & $\begin{array}{l}\text { Coordinated contact } \\
\text { sensor data with } \\
\text { crossing traffic } \\
\text { vehicle data }\end{array}$ & $\begin{array}{l}\text { - Wireless fiber optic } \\
\text { strain gauge } \\
\text { - Temperature and } \\
\text { environmental } \\
\text { sensors } \\
\text { - Weigh-in motion } \\
\text { station along with } \\
\text { vehicle monitoring } \\
\text { system } \\
\text { - Close circuit camera }\end{array}$ & $\begin{array}{l}\text { Embedded algorithm } \\
\text { in the weigh-in } \\
\text { motion system } \\
\text { with video capture } \\
\text { function }\end{array}$ & $\begin{array}{l}\text { Establishment of a } \\
\text { baseline from the } \\
\text { collected data to use } \\
\text { in future }\end{array}$ & $\begin{array}{l}\text { - Wireless data } \\
\text { transmission is } \\
\text { available } \\
\text { - Close circuit camera is } \\
\text { mounted on a tower } \\
\text { which does not } \\
\text { interrupt the regular } \\
\text { traffic movement }\end{array}$ & $\begin{array}{l}\text { Close circuit camera is } \\
\text { susceptible to } \\
\text { variable weather } \\
\text { condition }\end{array}$ & $\begin{array}{l}\text { Real-world } \\
\text { application }\end{array}$ & $\begin{array}{c}\text { Darwish et } \\
\text { al. [66] }\end{array}$ \\
\hline \multirow{2}{*}{$\begin{array}{l}\text { ITS- } \\
\text { informed } \\
\text { bridge } \\
\text { response } \\
\text { study for } \\
\text { critical } \\
\text { events }\end{array}$} & $\begin{array}{l}\text { Monitored critical } \\
\text { events (i.e., } \\
\text { bridge vibrations) } \\
\text { using traffic } \\
\text { camera }\end{array}$ & $\begin{array}{l}\text { - Sensors } \\
\text { (acceleration and } \\
\text { temperature) } \\
\text { installed on the } \\
\text { bridge } \\
\text { - Video camera }\end{array}$ & $\begin{array}{l}\text { Event detection } \\
\text { technique }\end{array}$ & $\begin{array}{l}\text { Inspection and } \\
\text { recording of the } \\
\text { events which may } \\
\text { cause increased } \\
\text { vibration in bridge } \\
\text { structure }\end{array}$ & $\begin{array}{l}\text { Video clip regarding an } \\
\text { activity can be } \\
\text { recorded and logged } \\
\text { into a database }\end{array}$ & $\begin{array}{l}\text { Environment has } \\
\text { adverse effect on } \\
\text { video camera } \\
\text { performance }\end{array}$ & $\begin{array}{l}\text { Experimental } \\
\text { study }\end{array}$ & $\begin{array}{c}\text { Basharat et } \\
\text { al. [68] }\end{array}$ \\
\hline & $\begin{array}{l}\text { Studied wireless } \\
\text { video-enhanced } \\
\text { traffic monitoring } \\
\text { system }\end{array}$ & $\begin{array}{l}\text { - Wireless sensors on } \\
\text { bridge } \\
\text { superstructure } \\
\text { - Video camera } \\
\text { - Accelerometer } \\
\text { installed on the } \\
\text { bridge }\end{array}$ & $\begin{array}{l}\text { Automated image } \\
\text { processing } \\
\text { techniques and } \\
\text { peak-picking } \\
\text { algorithm to } \\
\text { identify bridge's } \\
\text { modal frequencies }\end{array}$ & $\begin{array}{l}\text { Quantification of the } \\
\text { vehicle number and } \\
\text { finding the } \\
\text { correlation between } \\
\text { its effect with the } \\
\text { response of the bridge } \\
\text { structure }\end{array}$ & $\begin{array}{l}\text { - Traffic monitoring } \\
\text { camera does not } \\
\text { interrupt traffic flow } \\
\text { - Wireless sensors allow } \\
\text { reconfiguration of } \\
\text { sensor locations } \\
\text { - Wireless system is less } \\
\text { labor intensive than } \\
\text { cabled monitoring } \\
\text { system }\end{array}$ & $\begin{array}{l}\text { Image capturing } \\
\text { performance of } \\
\text { camera can be } \\
\text { hindered by } \\
\text { environmental } \\
\text { conditions (i.e., rain, } \\
\text { fog etc.) }\end{array}$ & $\begin{array}{l}\text { Experimental } \\
\text { study }\end{array}$ & $\begin{array}{l}\text { Loh et al. } \\
\text { [69] }\end{array}$ \\
\hline
\end{tabular}


TABLE I (Cont.)

STUDIES ON ITS-INFORMED SHM

\begin{tabular}{|c|c|c|c|c|c|c|c|c|}
\hline $\begin{array}{l}\text { Key } \\
\text { feature }\end{array}$ & $\begin{array}{c}\text { Main aspect of the } \\
\text { research }\end{array}$ & $\begin{array}{c}\text { Devices/ } \\
\text { Sensors/Station }\end{array}$ & Strategies & $\begin{array}{l}\text { Issues investigated in } \\
\text { the research }\end{array}$ & Advantages & Limitations & $\begin{array}{c}\text { Type of } \\
\text { project }\end{array}$ & Source \\
\hline \multirow{3}{*}{$\begin{array}{l}\text { ITS- } \\
\text { informed } \\
\text { complete } \\
\text { bridge } \\
\text { managem } \\
\text { ent } \\
\text { system }\end{array}$} & $\begin{array}{l}\text { Monitored vehicle } \\
\text { load for integrating } \\
\text { SHM and } \\
\text { intelligent bridge } \\
\text { management }\end{array}$ & $\begin{array}{l}\text { - Professional } \\
\text { meteorological } \\
\text { station in the } \\
\text { middle main span } \\
\text { of the bridge } \\
\text { - Temperature and } \\
\text { humidity sensor in } \\
\text { steel box girders } \\
\text { and steel arc tower } \\
\text { - Weigh-in motion } \\
\text { station }\end{array}$ & $\begin{array}{l}\text { Embedded algorithm } \\
\text { in the weigh-in } \\
\text { motion system } \\
\text { with video capture } \\
\text { function }\end{array}$ & $\begin{array}{l}\text { Assistance for the } \\
\text { management and } \\
\text { control of overweight } \\
\text { vehicles by collecting } \\
\text { vehicle weight and } \\
\text { license plate number }\end{array}$ & $\begin{array}{l}\text { - Real-time and accurate } \\
\text { vehicle axle loads can be } \\
\text { collected } \\
\text { - The accuracy of the } \\
\text { weigh-in motion station } \\
\text { to record speed and } \\
\text { weight are tolerable }\end{array}$ & $\begin{array}{l}\text { - The initial installation } \\
\text { and maintenance cost of } \\
\text { weigh-in motion system } \\
\text { is high. } \\
\text { - Video capture } \\
\text { performance can be } \\
\text { affected by bad weather }\end{array}$ & $\begin{array}{l}\text { Real-world } \\
\text { application }\end{array}$ & $\begin{array}{l}\text { Chen et } \\
\text { al.[70] }\end{array}$ \\
\hline & $\begin{array}{l}\text { Developed software } \\
\text { to integrate both } \\
\text { real-time and } \\
\text { historic data of } \\
\text { SHM and traffic } \\
\text { monitoring }\end{array}$ & $\begin{array}{l}\text { - SHM sensors } \\
\text { (dynamic strain } \\
\text { sensors, static } \\
\text { strain sensors, } \\
\text { temperature } \\
\text { sensors) fixed with } \\
\text { the bridge } \\
\text { - Video surveillance } \\
\text { camera } \\
\end{array}$ & $\begin{array}{l}\text { Embedded } \\
\text { algorithms for } \\
\text { statistical analysis, } \\
\text { data visualization } \\
\text { and reporting }\end{array}$ & $\begin{array}{l}\text { Management of large } \\
\text { amounts of SHM and } \\
\text { traffic monitoring } \\
\text { data }\end{array}$ & $\begin{array}{l}\text { Real-time and/or on- } \\
\text { demand access to data } \\
\text { (both live or historic) is } \\
\text { available } \\
\text { - Software package is user } \\
\text { friendly and it is } \\
\text { oriented for a wide- } \\
\text { ranging audience }\end{array}$ & $\begin{array}{l}\text { Performance of video } \\
\text { surveillance camera can } \\
\text { be hindered due to } \\
\text { adverse weather }\end{array}$ & $\begin{array}{l}\text { Real-world } \\
\text { application }\end{array}$ & $\begin{array}{l}\text { Glisic et } \\
\text { al. [71] }\end{array}$ \\
\hline & $\begin{array}{l}\text { Determined } \\
\text { maintenance work } \\
\text { frequency }\end{array}$ & $\begin{array}{l}\text { Vibration, } \\
\text { temperature and } \\
\text { strain sensors } \\
\text { connected to the } \\
\text { bridge } \\
\text { - Video cameras } \\
\end{array}$ & $\begin{array}{l}\text { Time series } \\
\text { subsequence } \\
\text { clustering } \\
\text { technique }\end{array}$ & $\begin{array}{l}\text { Identification of the } \\
\text { traffic events by } \\
\text { bridge response }\end{array}$ & $\begin{array}{l}\text { A scalable implementation } \\
\text { of the proposed } \\
\text { framework is } \\
\text { demonstrated }\end{array}$ & $\begin{array}{l}\text { Depending on the input } \\
\text { data, some undesirable } \\
\text { behavior can be } \\
\text { observed from the } \\
\text { classic subsequence } \\
\text { clustering method }\end{array}$ & $\begin{array}{l}\text { Real-world } \\
\text { application }\end{array}$ & $\begin{array}{l}\text { Vespier et } \\
\text { al. [72] }\end{array}$ \\
\hline
\end{tabular}


this image processing burden and improve the traffic identification results. ITS needs reliable traffic information (i.e., traffic volume, vehicle speed) to optimize traffic signals, and to detect and manage incidents. Xue developed an integrated transportation monitoring systems to simultaneously collect the traffic speed and monitor the pavement health condition [77].

\section{B. SHM-informed ITS to Determine Vehicle Characteristics Data}

To determine the individual vehicle configuration and the weight of the moving vehicle, Wang et al. integrated the conventional infrastructure monitoring systems such as in-situ sensors with traffic classification system and weigh-in motion system [78]. Using this integrated monitoring system, the authors introduced a back calculation method to infer parameters (e.g., vehicle weight and speed, and passing vehicle configurations) from the strain measurements. The back-calculated speed was reported to exactly match with the speed derived from a speed gun, and the distance between axles and calculated tire weights are found to have excellent agreement with the actual axle spacing and weights. In their study, Gonzalez and Karoumi also integrated ITS with SHM to determine vehicle load [79]. From their research, authors observed that a bridge system deteriorates mainly due to traffic load and other environmental factors. With the help of the bridge weigh-in motion system, they proposed a railway traffic monitoring technique for the Soderstorm Bridge in central Stockholm, Sweden. This weigh-in motion system has two strain gauges (i.e., SHM sensor). Data extracted from these gauges help to determine the train axle spacing and the axle load. Results from the research show an average of 22 train crossings per hour on the instrumented track. With a $95 \%$ confidence level, accuracy of the estimated load by the bridge weigh-in motion system was within $15 \%$ for the calculated axle load and $8 \%$ for bogie load.

Fraser et al. used SHM sensor (i.e., accelerometers) and ITS device (i.e., video camera) to detect individual vehicle in the Voigt Drive/Interstate-5 bridge test bed in the University of California, San Diego campus [80]. Continuous timesynchronized visual and accelerometer data are made available through a secured web portal. The System resonant characteristics were monitored by generating and viewing the frequency domain displays of time histories. Although the bridge is affected by the major traffic crossing below the I-5 corridor, the developed automated system identified the bridge vibration induced by the crossing traffic on the bridge deck using stabilization diagrams. As per the stabilization diagrams, a bridge physical vibration mode is only considered if: 1) the natural frequency of the bridge deviates by less than $1 \%$ from the models; 2) the modal assurance criterion between the mode shape is more than $95 \%$; 3) the damping ratio is less than $20 \%$ and positive; and 4) the modal parameters satisfy the previous three conditions for minimum 10 times. To determine the exact vehicle location on the bridge, markers were used on both sidewalks at known locations. By processing the video signal records, both vehicle speed and location are determined later. To detect the moving vehicles from the video stream, the background subtraction method was used, which compares and separates the pixels of each frame that have different properties from the updated background scene. Using this subtraction method the vehicles from the background image are separated.

In their study of video and contact sensor responses, Chang et al. [81] developed a computer vision algorithm to identify, track and classify vehicles. Subsequently, Gandhi et al. studied the synchronization of data captured by contact and visual instruments to identify, track, and classify each vehicle traveling across a bridge [82]. Such synchronization requires the use of video images to provide real-time estimations of the ambient excitation caused by traffic density and vehicle weight on the bridge. The corresponding data is then fed into the SHM pattern recognition algorithm. The authors found that the time series properties from seismic sensors and texture, shape, and color features collected from vision sensors is useful in classifying the recorded data into the detectable vehicle classes.

Review of recent literature highlights applications where traffic conditions and vehicle characteristics are investigated through visual aids and contact sensors. In order to plan traffic routing, it is necessary to correlate the traffic conditions and vehicle characteristics with their effects on the bridge structure. The reviewed studies have distinct strategies, advantages and limitations, which are summarized in Table II. In addition, Table II includes main research aspects, issues investigated in the projects, devices used and the project type.

\section{Challenges AND Future ReSEARCH Directions of INTEGRATION OF ITS AND SHM}

In Section VI and V, earlier research about the successful integrations of SHM sensors and ITS devices for both ITSinformed SHM and SHM-informed ITS is presented, where the coupling of ITS and SHM have improved the functionality of both systems. With time, technologies and functionalities of both ITS and SHM are anticipated to continually improve. More efforts are required to implement ITS, as this emerging system still has many challenges to overcome to achieve maturity as a practically applicable and, feasible technology [83] for ITS-SHM integration. Major challenges for proper integration of ITS and SHM are listed below along with the future research directions to address the challenges.

\section{A. Introduction of reliable data collection technology}

\section{1) Challenge}

SHM is mainly a data-driven decision making system, which needs a consistent flow of reliable data from the contact sensors, and visual instruments. Traffic monitoring devices, such as video cameras, however, cannot collect data in lessthan-ideal conditions such as at night or in poor weather. Shadow and low lighting conditions are the fundamental technical limitation of current computer vision systems, which are now integrated into many existing SHM applications [84]. Thus, proper introduction and implementation of timely and reliable data collection technology still remains a challenge. 
TABLE II

STUDIES ON SHM-INFORMED ITS

\begin{tabular}{|c|c|c|c|c|c|c|c|c|}
\hline Key feature & $\begin{array}{l}\text { Main aspect of the } \\
\text { research }\end{array}$ & Devices/Sensors/Station & Strategies & $\begin{array}{l}\text { Issues investigated in the } \\
\text { research }\end{array}$ & Advantages & Limitations & Type of project & Source \\
\hline $\begin{array}{l}\text { SHM-informed } \\
\text { ITS to } \\
\text { determine } \\
\text { traffic } \\
\text { operational } \\
\text { condition }\end{array}$ & $\begin{array}{l}\text { Investigate image } \\
\text { processing of } \\
\text { video records } \\
\text { about background } \\
\text { model, image } \\
\text { segmentation } \\
\text { process, shadow } \\
\text { suppression } \\
\text { process and object } \\
\text { matching method }\end{array}$ & $\begin{array}{l}\text { - Traffic video } \\
\text { monitoring device } \\
\text { installed on the mid- } \\
\text { span of the main } \\
\text { navigation channel } \\
\text { bridge } \\
\text { - Inductive loop } \\
\text { - Structural response } \\
\text { monitoring devices } \\
\text { (strain gauge, } \\
\text { accelerometer) }\end{array}$ & $\begin{array}{l}\text { Image } \\
\text { processing } \\
\text { algorithm }\end{array}$ & $\begin{array}{l}\text { Determination of the } \\
\text { traffic volume, traffic } \\
\text { density, vehicle speed }\end{array}$ & $\begin{array}{l}\text { Due to relatively low } \\
\text { implementation cost, no } \\
\text { interference with traffic and } \\
\text { no damage to road, use of } \\
\text { video camera is widespread }\end{array}$ & $\begin{array}{l}\text { Use of inductive loop and } \\
\text { WIMS to support video } \\
\text { camera increases the } \\
\text { operational and maintenance } \\
\text { cost of the system }\end{array}$ & $\begin{array}{l}\text { Experimental } \\
\text { study }\end{array}$ & $\begin{array}{c}\text { Sun and Sun } \\
{[60]}\end{array}$ \\
\hline \multirow{5}{*}{$\begin{array}{l}\text { SHM-informed } \\
\text { ITS to determine } \\
\text { vehicle } \\
\text { characteristics } \\
\text { data }\end{array}$} & $\begin{array}{l}\text { Monitor railway } \\
\text { traffic }\end{array}$ & $\begin{array}{l}\text { - Contact sensors } \\
\text { (accelerometers, strain } \\
\text { gauges) } \\
\text { - Weigh-in motion } \\
\text { station } \\
\end{array}$ & $\begin{array}{l}\text { Embedded } \\
\text { algorithm in } \\
\text { bridge weigh- } \\
\text { in motion } \\
\text { station } \\
\end{array}$ & $\begin{array}{l}\text { Estimation of the axle } \\
\text { load and axle spacing }\end{array}$ & $\begin{array}{l}\text { The proposed algorithm } \\
\text { requires simple } \\
\text { computational effort and } \\
\text { uses only two strain gauges }\end{array}$ & $\begin{array}{l}\text { The sensor placement is not the } \\
\text { most ideal for traffic load } \\
\text { estimation purpose }\end{array}$ & $\begin{array}{l}\text { Experimental } \\
\text { study }\end{array}$ & $\begin{array}{l}\text { Gonzalez and } \\
\text { Karoumi [79] }\end{array}$ \\
\hline & $\begin{array}{l}\text { Perform back } \\
\quad \text { calculation from } \\
\text { synchronized data } \\
\text { captured by } \\
\text { sensors }\end{array}$ & $\begin{array}{l}\text { - Weigh-in motion } \\
\text { station } \\
\text { - Sensors (load cells, } \\
\text { thermocouple, strain } \\
\text { gauges, moisture } \\
\text { sensor) installed on the } \\
\text { bridge }\end{array}$ & $\begin{array}{l}\text { Back calculation } \\
\text { process (from } \\
\text { response of } \\
\text { strain gauges) }\end{array}$ & $\begin{array}{l}\text { - Detection, tracking, } \\
\text { and classification of the } \\
\text { vehicles traveling } \\
\text { across the surface of a } \\
\text { bridge } \\
\text { Passing vehicles, } \\
\text { configuration }\end{array}$ & $\begin{array}{l}\text { - The time requirement for } \\
\text { back calculation analysis is } \\
\text { low } \\
\text { - It has ignorable storage } \\
\text { requirement compared to } \\
\text { image processing method } \\
\text { - Low cost monitoring system } \\
\text { has multiple functionalities } \\
\text { and high efficiency }\end{array}$ & $\begin{array}{l}\text { There was no arrangement to } \\
\text { consider different loading } \\
\text { condition of vehicle and } \\
\text { effect of temperature on } \\
\text { pavement }\end{array}$ & $\begin{array}{l}\text { Experimental } \\
\text { study }\end{array}$ & Wang et al. [78] \\
\hline & $\begin{array}{l}\text { Develop an } \\
\text { integrated } \\
\text { structural } \\
\text { monitoring } \\
\text { framework to } \\
\text { detect the moving } \\
\text { traffic }\end{array}$ & $\begin{array}{l}\text { - Accelerometer on } \\
\text { bridge superstructure } \\
\text { - Digital camera installed } \\
\text { on light post }\end{array}$ & $\begin{array}{l}\text { Stochastic } \\
\quad \text { subspace } \\
\text { identification } \\
\text { algorithm and } \\
\text { image } \\
\text { processing }\end{array}$ & $\begin{array}{l}\text { Detection and tracking of } \\
\text { vehicles }\end{array}$ & $\begin{array}{l}\text { Established sensor network } \\
\text { does not interfere with } \\
\text { traffic and it is not affected } \\
\text { by the ambient weather } \\
\text { conditions } \\
\text { - Real-time data transmission } \\
\text { was secured through high } \\
\text { speed internet }\end{array}$ & $\begin{array}{l}\text { Enhancement of the vehicle- } \\
\text { identification algorithm to } \\
\text { handle merging vehicles, and } \\
\text { implementation of the } \\
\text { shadow suppression } \\
\text { algorithm is required }\end{array}$ & $\begin{array}{l}\text { Experimental } \\
\text { study }\end{array}$ & Fraser et al. [80] \\
\hline & $\begin{array}{l}\text { Use contact and } \\
\text { vision sensors to } \\
\text { identify, track and } \\
\text { classify vehicles }\end{array}$ & $\begin{array}{l}\text { - Contact sensors } \\
\text { (accelerometers, strain } \\
\text { gauges) connected to } \\
\text { the bridge } \\
\text { - Video camera }\end{array}$ & $\begin{array}{l}\text { Computer vision } \\
\text { algorithms }\end{array}$ & $\begin{array}{l}\text { Detection, tracking and } \\
\text { classification of } \\
\text { vehicles }\end{array}$ & $\begin{array}{l}\text { Data collected by the } \\
\text { combined contact and video } \\
\text { sensors increase the } \\
\text { reliability of the whole } \\
\text { system }\end{array}$ & $\begin{array}{l}\text { Image capturing performance of } \\
\text { camera can be hindered by } \\
\text { environmental conditions }\end{array}$ & $\begin{array}{l}\text { Experimental } \\
\text { study }\end{array}$ & Chang et al. [81] \\
\hline & $\begin{array}{l}\text { Use multiple } \\
\text { modalities that } \\
\text { includes contact } \\
\text { sensors and } \\
\text { distributed video } \\
\text { array (DIVA) }\end{array}$ & $\begin{array}{l}\text { - Contact sensors } \\
\text { (accelerometers, strain } \\
\text { gauges) along the } \\
\text { roadway } \\
\text { - Video camera on street } \\
\text { lights or neighboring } \\
\text { buildings }\end{array}$ & $\begin{array}{l}\text { Image-based } \\
\quad \text { vehicle } \\
\text { identification } \\
\text { and tracking } \\
\text { algorithms }\end{array}$ & $\begin{array}{l}\text { Detection, tracking and } \\
\text { classification of } \\
\text { vehicles }\end{array}$ & $\begin{array}{l}\text { Data collected by the video } \\
\text { sensors and seismic sensors } \\
\text { are more reliable than using } \\
\text { single sensors }\end{array}$ & $\begin{array}{l}\text { - Image capturing performance } \\
\text { of camera can deteriorate } \\
\text { environmental conditions } \\
\text { - The peak gap in strain gauge } \\
\text { response for small vehicles } \\
\text { was unreliable and the } \\
\text { response had noticeable } \\
\text { spread } \\
\end{array}$ & $\begin{array}{l}\text { Experimental } \\
\text { study }\end{array}$ & $\begin{array}{l}\text { Gandhi et al. } \\
\text { [82] }\end{array}$ \\
\hline
\end{tabular}




\section{2) Future Research Direction}

The following techniques, if implemented can contribute to both SHM and ITS system by maintaining the reliability of the collected data.

\section{- Mobile vibration-based bridge health monitoring}

A mobile unit (i.e. a probe vehicle) traversing a bridge constitutes a dynamic system with multi-degree-of-freedom. The inertial, damping, and stiffness properties of the mobile unit as well as the bridge govern the response from the system. Any change in these properties over time (e.g. change related to the bridge aging or accumulated lifetime damage) causes changes in the combined system's response. Thus, changes in the vehicle vibrations are attributable to changes in either pavement or in bridge stiffness. The changes in the vibration response from changes in pavement surface and bridge stiffness are expected to be concentrated within vastly different frequency ranges. It is possible, however, through proper data cleaning, filtering, and interrogation techniques, to develop such a scheme. The spatial integrity of the collected data will be assured with high-accuracy GPS positioning. GPS technology is also useful in verifying the displacement of the bridge structure, as indicated in the Knecht and Manetti study [85]. Fig. 1 shows a GPS-instrumented vehicle collecting data from its built-in accelerometer. This vehicle can also be used to collect traffic data (i.e. vehicle speed, headway, number of stops). According to Kim et al., using vehicles integrated with

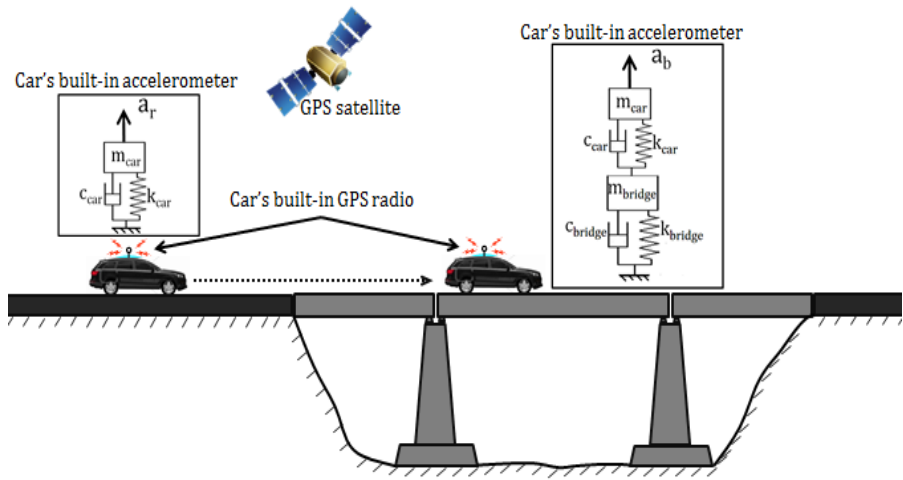

Fig. 1. Schematic diagram of detecting bridge dynamic signatures.

accelerometers reduces both the installation and maintenance cost of additional wireless communication sensors for vehiclebridge monitoring [86]. This system can potentially serve as a reliable data source for the interim transitional period before the Connected Vehicle Technology (CVT) is fully matured and implemented, where connected vehicles can communicate and exchange data with other vehicles and/or bridge infrastructure through wireless communication.

- Collection of infrastructure information with CVT

FHWA developed a Connected Vehicle Reference Implementation Architecture (CVRIA) to show the primary interfaces in different CVT applications and to prioritize activities regarding standards development [87]. The 'Infrastructure Management' application from CVRIA is developed to monitor and maintain the performance of an infrastructure in a connected vehicle environment [88]. Fig. 2 shows a typical example of bridge infrastructure management in a connected vehicle environment. Here the maintenance and construction management center (MCMC) receives the connected vehicle generated vehicle size and vehicle loading information from TMC, and SHM sensor-based bridge health condition data from the bridge management center (BMC).

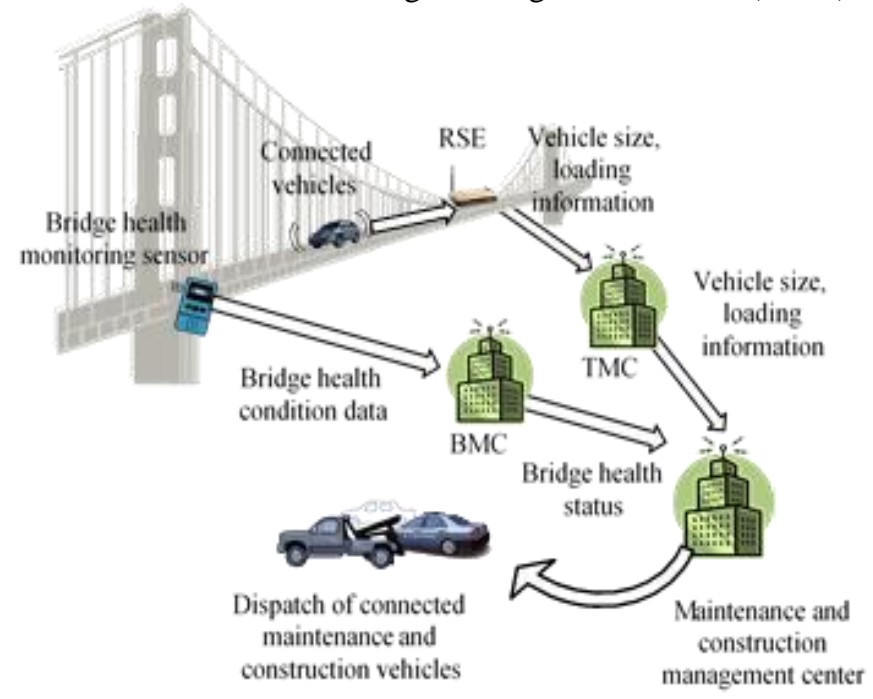

Fig. 2. Connected vehicle system incorporated bridge infrastructure management system

Once bridge damage is identified, immediate action is taken by the MCMC (e.g. the immediate dispatch of a bridge maintenance and construction vehicle). In addition to the vehicle characteristics data, connected vehicles can provide data on adverse weather conditions and support the integration of weather data with road condition and traffic operational condition data [89]-[91]. CVT also offers a cost effective pavement monitoring system [92]. Data collected from connected vehicles can be integrated with existing pavement deterioration forecasting models to estimate the time-wavelength-intensity-transform (i.e., a wavelength-unbiased characterization of pavement roughness from a wide range of vehicle types and speeds) and proportionality constant (i.e., proportion of the road impact factor and the international roughness index) providing a repeatable low-cost performance measure of the pavement.

\section{- Automated mobile corrosion monitoring system}

Although the corrosion of the reinforcing steel within a bridge has a direct consequence on infrastructure sustainability, steel bar corrosion measurement remains a challenge where these steel bars are embedded in the concrete. An automated mobile corrosion measurement system has been developed to address this difficulty [93], [94]. For detecting and measuring different types of surface corrosion, the use of a digital fringe projection technique with a high-resolution camera is studied by Huang et al. [95]. However, further research is necessary for evaluating the new generation of corrosion sensors [96] in a mobile vehicle-based data collection environment. Specifically, a new reliable corrosion data acquisition system for monitoring the infrastructure must be established which can acquire and transfer accurate corrosion data in real time. Using connected vehicles, collected data can be transferred from the corrosion monitoring system to BMC without any incurring additional costs of deployment in the infrastructure. 
B. Implementation of data infrastructure for Big Data Analytics

\section{1) Challenge}

Data analytics is used to derive useful information from raw data extracted from different SHM sensors (e.g., strain gauges, accelerometers), ITS devices (e.g., traffic surveillance camera, inductive loop detectors), cell phones, weather stations and social media (e.g., Facebook, Twitter) or news feeds. Apart from a few studies about the distributed data acquisition system [71], [72], very limited literature has addressed the challenges associated with data analytics for ITS-SHM integrated systems. Knobb et al. demonstrated the usefulness of data analytics for monitoring the Hollandse Brug. Bridge, Netherland which has 145 sensors [97]. They identified the bridge health monitoring application as a large complex data analytics application in terms of data capture, management, analysis and reporting. In this study, the monitoring system installed in the Hollandse Brug. Bridge, Netherland has 145 sensors. These sensors produce $56 \mathrm{kB}$ of data per second, which results in about 5 GB data per day. To broadcast realtime traffic status in their website, the video camera produces a data stream with very low latency. Data from all the highfrequency sensors are stored in the data warehouse for permanent storage. It is not possible to manage the large amount of real-time data with high frequency using existing data mining approaches, which require either the data to be inmemory or to be repeatedly scanned on the disc. Knobb et al. have recommended the use of a specific data analytics method called "Grid Technique" for bridge health monitoring. Thus, data analytics can support SHM offering a feasible solution for SHM to manage the acquired raw data. To assess the bridge condition and manage traffic in real-time, continuous data streaming from multiple SHM and ITS sensors is needed. The data collected from vastly different ITS and SHM sensors is aggregated and correlated according to temporal requirement of the SHM and ITS applications. Data delivery delay from the data sources to data users can increase due to the challenges associated with real-time data extraction and processing from a large number of SHM sensors, multiple ITS devices (i.e., video camera, connected vehicles, roadside equipment or RSE for connected vehicles) and other data sources (i.e., weather stations, cell phones, social media). The primary challenge for the combined SHM and ITS involve the data aggregation, data processing and data redistribution according to the specific temporal requirement of bridge management and traffic management applications. These requirements highlight the necessity of Big Data Analytics for the integrated SHM-ITS system. Within the scope of both ITS-informed SHM and SHM-informed ITS systems, Big Data Analytics tools are needed to support: 1) the enormous amount of data generated from SHM sensors and ITS devices; 2) the different data arrival rate from multiple data sources (e.g., SHM and ITS sensors); 3) the different data format standard (e.g., PDF, CSV, structured/unstructured XML etc.) of various sources, sampling rates, and types of data generated from SHM sensors and ITS devices [98], [99]; and 4) the potential of data uncertainty (i.e., abnormality or noise in data) due to sudden ITS and/or SHM sensor failures. Vespier et al. have identified the inability of traditional tools to handle the amount of data generated by a group of bridge sensors over a long-time range [72]. Big Data Analytics tools are needed to handle continuous streaming of massive data with varying velocity, accuracy and in vastly different format produced by both the SHM and ITS system. The design and implementation of data infrastructures to support ITS-SHM integration remains one of the greatest hurdles.

\section{2) Future Research Direction}

For integrated ITS-SHM applications, a data collection system could consist of onboard sensors from connected vehicles, RSE for connected vehicles, SHM sensors, personal devices (e.g. cell phones, portable computers) and online media, which would produce large amounts of data that cannot be analyzed using traditional data analysis tools. By definition, Big Data implies that size of data sets cannot be possible to capture, curate, manage and process using traditional software tools within a reasonable time frame. Previous studies identified the distributed data acquisition system for ITS-SHM integrated system at a local level without considering multitier data infrastructure from local level to national level using different middleware systems and technologies for Big Data [71]-[72]. To capture the aggregated data flows from numerous ITS and SHM applications, a multi-tier data infrastructure can ensure the maximum availability of such filtered data. Fig. 3 presents a conceptual architecture for integrated SHM-ITS data infrastructure to serve the combined SHM-ITS applications using different middleware systems and technologies for Big Data. At the local level, raw data is collected from different sources (e.g. SHM sensors, connected vehicles, RSE for connected vehicle, traffic monitoring camera, mobile phones, social media), and stored in city TMCs. Once processed, data from all regional level BMC and TMCs are aggregated and forwarded to the state level data center. Finally a national-level massive data warehouse will store and archive the data for further use. Raw data from different sources of integrated ITS-SHM system at a local level typically come in under XML/JSON format [100]. At regional level, document store, which is a component of the information infrastructure to support rapid, large-scale data ingestion in the absence of a unified data schema, can use the most popular open source solutions such as MongoDB [101] and CouchBase [102]. In the next stage, the data from the data document needs to be normalized, indexed, and integrated with other data to support near-real-time analytics, trend detections, and forecasting. This requires the implementation of extensible records store solutions to extract, transfer and load (ETL) to manage the unstructured, dynamic, and temporal characteristics of ITS and SHM data. HBase [103], HyperTable [104], HPCC [105], and Cassandra [106] are the available solutions for implementing extensible records for ITS and SHM. Accumulo [107] can be used to understand how the additional overhead required for security and privacy affects the overall performance of the integrated ITS-SHM infrastructure. To support very strict service-level agreement (SLA) demands of integrated ITS-SHM applications, inmemory databases (SQL or NoSQL), such as VoltDB [108] and MySQL [109] can be used. CouchBase, Accumulo, and HPCC can be used as options to perform a comprehensive evaluation of the entire infrastructure on different aspects 


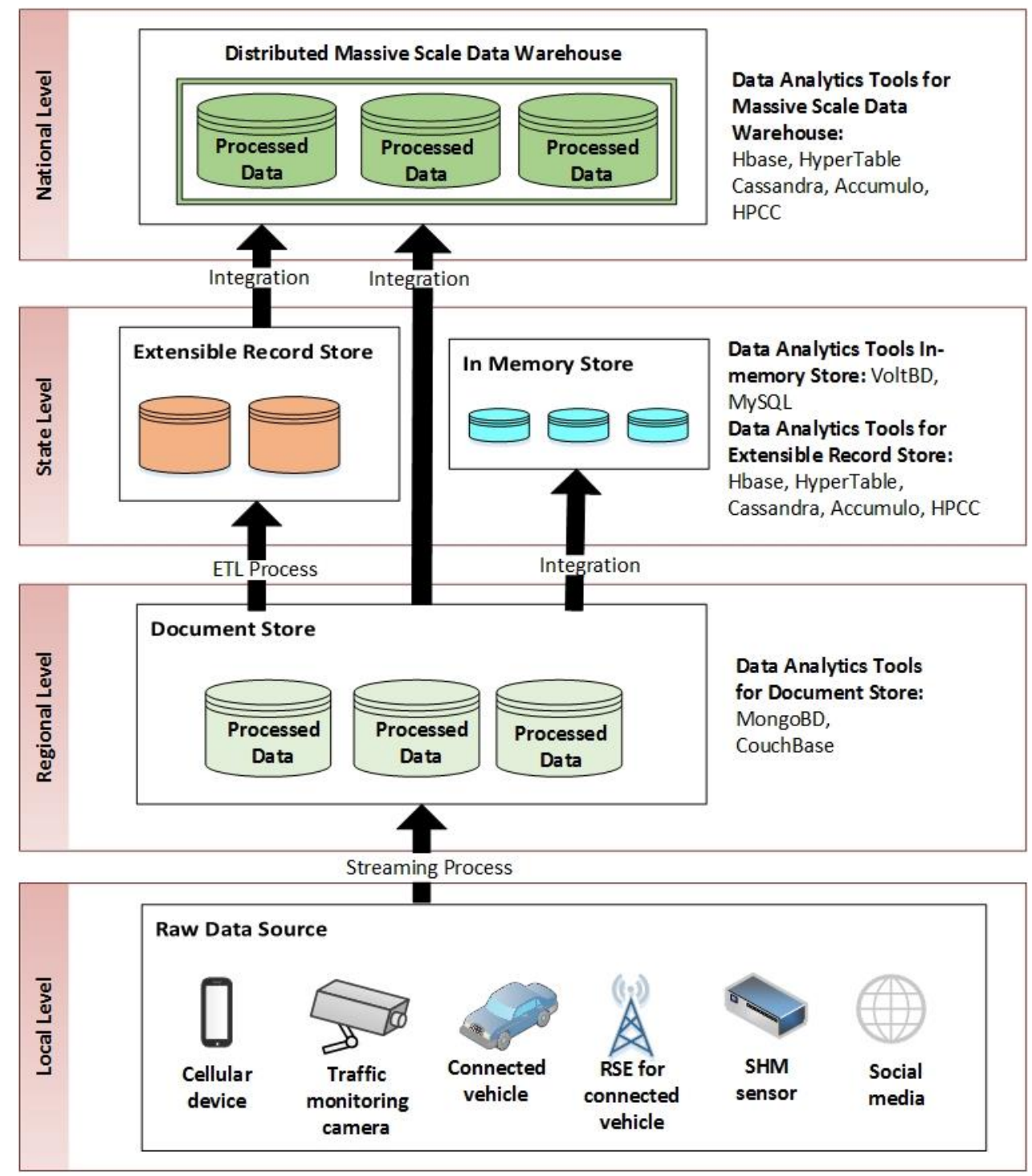

Fig. 3.Architecture for Integrated SHM-ITS Data Infrastructure

including performance, integration ability, scalability, and benefit/cost tradeoffs. Such a system will have two major benefits for ITS-SHM. First, as the processed data is stored in different level, it will help to prevent the impact of any performance degradation or failure of critical transportation infrastructure, which may have catastrophic consequences. Second, the data storage will be accessible and available 24/7 for any applications for traffic operations and structural health monitoring

\section{Institutional Coordination Requirement}

1) Challenge

For an integrated SHM-ITS system, operation and maintenance of the aging critical highway bridges in a safe, efficient, and cost-effective manner require coordination between multidisciplinary agencies [62]. Coordination between different SHM and ITS related agencies can ensure proper handling and management of massive amount of data, which will be collected from bridge health monitoring sensors and ITS devices. As discussed earlier (Section VI Subsection A), in a connected vehicle aided SHM system, data will be transferred between centers (i.e., BMC, TMC, MCMC), connected vehicles, SHM sensors and RSE for connected vehicles. Bridge condition monitoring, traffic condition monitoring, and bridge maintenance activities may be handled by different agencies who are responsible for different centers (e.g., bridge management authority for BMC, traffic management authority for TMC, bridge maintenance authority for MCMC). A successful coordination between the respective stakeholder agencies is critical for proper SHM-ITS integration. In any standalone ITS and SHM system, each agency has its own objectives to accomplish. For instance, $\mathrm{BMC}$ is responsible for monitoring and managing bridge health condition in a standalone SHM system, whereas a key objective of TMC is to monitor real-time traffic condition and manage traffic in a standalone ITS. MCMC has its own functions, which include supervising bridge maintenance and construction activities. Standards and practices for data collection, processing and distribution vary from agency to agency. These variations in agency-specific task objectives, standards and protocols necessitate future research on institutional coordination among stakeholder agencies for a successful ITS-SHM integration. 


\section{2) Future Research Direction}

For an integrated ITS-SHM system, a successful institutional coordination will lead to the proper management of diverse activities (i.e., bridge health condition monitoring, real-time traffic condition monitoring, bridge maintenance and construction activities management) of different agencies which are stakeholders in SHM-ITS integration. Coordination will occur only when agencies will have extended objectives to serve the integrated SHM-ITS system beyond meeting the objectives of standalone SHM or ITS. Future research will include the development of a joint concept of operations developed collaboratively by both SHM and ITS agencies, and development of protocols and standards to support SHM-ITS integration. Fig. 3 shows a big-data architecture required to collect, process and distribute massive amount of data from multiple SHM and ITS sources for an efficient operation of integrated SHM-ITS system. Since different agencies will be involved to collect, manage and distribute data at local, regional, state and/or national levels in an integrated SHM-ITS system, inter-agency coordination and data exchange protocols are needed. By efficiently collecting and fusing data received from different SHM sensors and ITS devices, and managing the data and distributing the collected data to different agencies and other users according to their respective requirements, a successful and sustainable big data analytics framework for the integrated SHM-ITS system can be implemented.

\section{CONCLUSIONS}

The authors observed, through a detailed review, that the reliability and efficiency of both ITS and SHM system can be improved where these two systems are properly integrated. Visual bridge inspection routines used by most bridge management systems have proven inadequate, as clearly evidenced by the recent catastrophic failures of major bridges. Consequently, extensive research has been undertaken to increase the reliability and consistency of bridge condition assessment systems. Though NDI methods are useful in limiting the flaws of visual inspection on an interval-basis, they are time-consuming and only performed if damage is suspected within the structure. SHM systems, however, are uniquely suited to continuously monitor the structural condition of a bridge in that they can immediately identify the onset of damage. SHM systems have proven to give reliable information in assessing the condition of the bridge structural systems, but excluding the effects of traffic acting on the bridge and environmental conditions, often lead to false positive or negative responses. Various state departments of transportation have supported the research necessary for integrating ITS and SHM. When integrated with SHM, ITS devices, such as video camera, traffic sensors, helped to locate the source of critical events, and to capture the bridge response under different traffic flow. The authors also found that data collected from SHM sensors, when incorporated with the ITS devices supported ITS applications to identify the traffic operational condition and necessary vehicle characteristics information. However, an efficient integrated ITS-SHM scheme requires determining the deficiencies of the existing data collection techniques, creating a standards-driven data infrastructure, and enhancing the institutional coordination needed to implement this infrastructure. Connected vehicles can be considered as a reliable data source to mitigate any false-diagnosis of SHM. In the near future, the existing trend of SHM data collection is expected to change drastically with the increasing market penetration of connected vehicles. With higher penetration of connected vehicles, the continuous flow of real time and reliable traffic information are possible. Probe vehicles, mobile vibration-based bridge monitoring systems and automated corrosion monitoring system are also expected to provide cost effective solutions for the continuous monitoring of bridges health condition. With the initiation of large-scale data infrastructure, and a strong coordinated interagency framework, long-term benefit from the integrated ITSSHM system can be ensured. Once the challenges are properly addressed, the incorporation of ITS technologies with SHM sensors can provide the system the ability to calibrate the bridge health monitoring systems depending on different realtime traffic conditions and vehicle characteristics on the bridge to significantly reduce erroneous results.

\section{ACKNOWLEDGMENT}

The authors would like to express their gratitude for Godfrey Kimball, Editor, College of Engineering and Science, Clemson University for editing the paper.

\section{REFERENCES}

[1] S. Alampalli, and K. C. Rehm, "Impact of I-35W Bridge Failure on State Transportation Agency Bridge Inspection and Evaluation Programs." in Proc. 42nd Structures Congress., Las Vegas, 2011. pp. 1019-1026.

[2] Collapse of I-35W Highway Bridge, Minneapolis, Minnesota August 1, 2007, Highway Accident Report NTSB/HAR- 08/03 PB2008-916203, National Transportation Safety Board, Washington, D.C., 2008.

[3] P. D. Thompson, E. P. Small, M. Johnson, and A. R. Marshall, "The Pontis bridge management system", in Structural Engineering International, IABSE, vol. 8, no. 4, pp. 303-308, 1998.

[4] W. Liu, H. Edd, C. Shen-en, and H. Garland, "A Study on Current Bridge Maintenance Policies," in Proc. 11th International Conference of Chinese Transportation Professionals, Nanjing, China. 2011, pp. 244254.

[5] M. E. Moore, B. M. Phares, B. A. Graybeal, D. D. Rolander, and G. A. Washer, "Reliability of visual inspection of highway bridges," FHWA, U.S. Dept. of Transportation, Washington, D.C., Rep. No. FHWA-RD01-020, 2001.

[6] J. Boyd, B. Birgisson, F. Christopher, and S. Cumming, (2005) "Nondestructive Testing for Advanced Monitoring and Evaluation of Damage in Concrete Material". [Online], Available: http://www.dot.state.fl.us/research-

center/Completed_Proj/Summary_SMO/FDOT_BC354_57_rpt.pdf

[7] M. Scott, A. Rezaizadeh, A. Delahaza, C. G. Santos, M. Moore, B. Graybeal, G. A. Washer, "A comparison of nondestructive evaluation methods for bridge deck assessment," NDT\&E International, vol. 36, no. 4 pp. 245-55, 2002.

[8] J. D. Lavender, (1976) Ultrasonic Testing of Steel Castings. Madison, WI: Steel Founders' Society of America. Available: https://sfsa.org/sfsa/pubs/misc/Ultrasonic\%20Testing.pdf

[9] M. Sansalone, "Impact-Echo: The Complete Story" in ACI Structural Journal, vol. 94, no. 6, pp. 777-786., 1997.

[10] K. Maser, (1994). "Ground Penetrating Radar Surveys to Characterize Pavement Layer Thickness Variations at GPS Sites." INFRASENSE Inc., Research Report SHRP-P397. Strategic Highway Research Program, National Research Council. Washington, DC.

[11] S. H. Gamidi, "Non Destructive Testing of Structures" Ph.D. dissertation, Indian Institute of Technology, Bombay, India, 2009. 
[12] Infrasense Incorporated (2006) "Feasibility of Using Ground Penetrating Radar (GPR) for Pavements, Utilities, and Bridges" Available: http://www.sddot.com/business/research/projects/docs/SD200505_Executive_Summary.pdf

[13] R. L. Reid, "The infrastructure crisis" in American Society of Civil Engineers, vol. 78, no. 1, pp. 40-65, 2008.

[14] ASCE (2013) "2013 Report Card for America's Infrastructure". Available: http://www.infrastructurereportcard.org/a/\#p/bridges/overview

[15] C. Boller, "Next generation structural health monitoring and its integration into aircraft design", in International Journal of Systems Science, vol. 31, no. 11, pp. 1333-1349, 2000.

[16] S. S. Jin, and H. J. Jung, "Vibration-based structural health monitoring using adaptive statistical method under varying environmental condition," in SPIE Smart Structures and Materials+ Nondestructive Evaluation and Health Monitoring, International Society for Optics and Photonics, 2000, pp. 90640T-90640T.

[17] H. Sohn, "Effects of environmental and operational variability on structural health monitoring" in Philosophical Transactions of the Royal Society A: Mathematical, Physical and Engineering Sciences, vol. 365, no. 1851, pp. 539-560, 2007.

[18] G.M. Sabnis, Y. Singh, A. Bambole, and G. Rai, (2014, December) "Structural Health Monitoring: A Dire Need of India," Available: http://www.dgc24.com/rminternational/en/wpcontent/uploads/2014/07/Structural-Health-Monitoring-Dire-NeedIndia-21st-SHM.pdf

[19] J. Collins, and M. Pietrzyk, "Wet and Wild: Developing and Evaluating an Automated Wet Pavement Motorist System," in Transportation Research Record: Journal of the Transportation Research Board 1759, pp. 19-27, 2001.

[20] Adot. (2014, December) "Road Weather Information System (Rwis) Public Web Site", Alaska Department of Transportation Available: http://roadweather.alaska.gov

[21] M. Chowdhury, and A. Sadek, "Fundamentals of Intelligent Transportation Systems Planning". Norwood, MA: Arctech House, 2003.

[22] Y. Ma, M. Chowdhury, A. Sadek, and M. Jeihani, "Real-time highway traffic condition assessment framework using vehicle-infrastructure integration (VII) with artificial intelligence (AI)," in IEEE Trans. Intell. Transp. Syst., 10(4), pp. 615-627, 2009.

[23] Y. Ma, M. Chowdhury, A. Sadek, and M. Jeihani, "Integration of vehicle infrastructure integration (VII) system and artificial intelligence (AI) for online travel time prediction," in IEEE Trans. Intell. Transp. Syst., vol. 13, no. 3, pp. 1369-1382, Sep. 2012.

[24] S. M. Khan, and M. Chowdhury, "ITS for One of the Most Congested Cities in the Developing World? Dhaka Bangladesh: Challenges and Potentials" in Intelligent Transportation Systems Magazine, IEEE, vol. 6, no. 2, pp. 80-83. 2014.

[25] USDOT, "Status of the Nation's Highways, Bridges, and Transit: Conditions and Performance. 2004". Print, 2004.

[26] Y. Ni, and K. Wong, (2012) "Integrating Bridge Structural Health Monitoring and Condition-Based Maintenance Management". Available: http://www.ndt.net/article/cshm2012/papers/v06.pdf

[27] R. Newman-Askins, L. Ferreira, and J. M. Bunker, "Intelligent transport systems evaluation: From theory to practice," in Jaeger, Vicki, Eds. Proceedings 21st ARRB and 11th REAAA Conference, Cairns, 2003.

[28] J. Meyer, R. Bischoff, G. Feltrin, and M. Motavalli, "Wireless Sensor Networks for Long-term Structural Health Monitoring," in Smart Structures and Systems, vol. 6, no. 3, pp. 263-275, 2010.

[29] D. R. Dhakal, K. Neupane, C. Thapa, and G. V. Ramanjaneyulu, "Different Techniques of Structural Health Monitoring," in International Journal of Civil, Structural, Environmental and Infrastructure Engineering Research and Development (IJCSEIERD), vol. 3, no. 2, pp. 55-66, 2013

[30] M. Kurata, J. Kim, Y. Zhang, J. P. Lynch, G. W. Van der Linden, V. Jacob, E. Thometz, P. Hipley, and L. H. Sheng, "Long-term assessment of an autonomous wireless structural health monitoring system at the new Carquinez Suspension Bridge," in Proc. SPIE 7983, Nondestructive Characterization for Composite Materials, Aerospace Engineering, Civil Infrastructure, and Homeland Security, San Diego, California, USA, 2011.

[31] D. Agdas, J. A. Rice, J. R. Martinez, \& I.R. Lasa, "Comparison of Visual Inspection and Structural-Health Monitoring As Bridge Condition Assessment Methods" in Journal of Performance of Constructed Facilities, 2015.
[32] Rytter, "Vibration based inspection of civil engineering structures," $\mathrm{Ph}$. D. Dissertation, Department of Building Technology and Structural Engineering, Aalborg University, Denmark, 1993.

[33] H. Sohn, C. Farrar, F. Hemez, and J. Czarnecki, J. (2003) "A Review of Structural Health Monitoring Literature 1996-2001", Los Alamos National Laboratory, USA.

[34] H. H. Nassif, M. Gindy, and J. Davis, "Comparison of laser Doppler vibrometer with contact sensors for monitoring bridge deflection and vibration" in NDT \& E International, vol. 38, no. 3, pp. 213-218, 2005.

[35] D. V. Jáuregui, K. R. White, C.B. Woodward, and K. R. Leitch, "Noncontact photogrammetric measurement of vertical bridge deflection," in Journal of Bridge Engineering, vol. 8, no. 4, pp. 212-222, 2003.

[36] Y. Fujino, and D. M. Siringoringo, "Structural health monitoring of bridges in Japan: an overview of the current trend" in Proc. of Fourth International Conference on FRP Composites in Civil Engineering (CICE2008), Zurich, Switzerland, 2008.

[37] C.R. Farrar, and K. Worden, "An Introduction to Structural Health Monitoring" in Philosophical Transactions of the Royal Society A: Mathematical, Physical and Engineering Sciences, vol. 365, no. 1851, pp. 303-315, 2007.

[38] S. Prabhu, and S. Atamturktur, "Feature Assimilation for Vibration Based Damage Detection," in Journal of Nondestructive Testing and Evaluation (ASTM), Vol. 41, No. 1, pp. 1-11, 2013.

[39] O. S. Salawu, "Detection of Structural Damage through Changes in Frequency: A Review," in Engineering Structures, vol. 19, no. 9, pp. 718-723, 1997.

[40] R. Farrar, S. W. Doebling, P. J. Cornwell, and E. G. Straser, "Variability of Modal Parameters Measured on the Alamosa Canyon Bridge," in Proc. 15th International Modal Analysis Conf., Orlando, FL, 1997, pp. 257-263.

[41] H. J. Fox, "The Location of Defects in Structures: A Comparison of the Use of Natural Frequency and Mode Shape Data," in Proc. of the 10th International Modal Analysis, San Diego, California, 1, 1992, pp. 522528

[42] W. M. West, "Illustration Of The Use Of Modal Assurance Criterion To Detect Structural Changes In An Orbiter Test Specimen," in Proc. Air Force Conference on Aircraft Structural Integrity, 1984, pp. 1-6.

[43] K. Pandey, M. Biswas, and M. M. Samman, "Damage Detection from Changes in Curvature Mode Shapes," in Journal of Sound and Vibration, vol. 145, no. 2, pp. 321-332, 1991.

[44] J. Chance, G.R. Tomlinson, and K. Worden, "A Simplified Approach to the Numerical and Experimental Modeling of the Dynamics of a Cracked Beam," in Proc. of the 12th International Modal Analysis Conference, 1994, pp. 778-785.

[45] N. Stubbs, J.-T. Kim, and K. Topole, "An Efficient and Robust Algorithm for Damage Localization in Offshore Platforms," in Proc. ASCE Tenth Structures Congress, 1992, pp. 543-546.

[46] U. Ojalvo, and D. Pilon, "Diagnostics for Geometrically Locating Structural Math Model Errors from Modal Test Data," in Proc. of 29th AIAA/ASME/ASCE/AHS/ASC Structures, Structural Dynamics, and Materials Conference, 1998, pp. 1174-1186.

[47] H. Sohn, C. R. Farrar, N. Hunter and K. Worden, "Applying the LANL Statistical Pattern Recognition Paradigm for Structural Health Monitoring to Data from a Surface-Effect Fast Patrol Boat," Los Alamos National Laboratory Report Los Alamos National Laboratory report LA13761-MS

[48] B. Yun, "Development and application of a vision-based displacement measurement system for structural health monitoring of civil structures," The US-Korea Workshop on Smart Structures Technology for Steel Structures, 2007.

[49] S. Patsias, and W. J. Staszewskiy, "Damage detection using optical measurements and wavelets," in Structural Health Monitoring, vol. 1, no. 1, pp. 5-22, 2002.

[50] R. Zaurin, and F. N. Catbas, "Structural health monitoring using video stream, influence lines, and statistical analysis" in Structural Health Monitoring, vol. 10, no. 3, pp. 309-332, 2011.

[51] Inaudi, and B. Glisic, (2008) "Overview of fiber optic sensing applications to structural health monitoring," in Symposium on Deformation Measurement and Analysis, pp. 1-10.

[52] H. N. Li, D. S. Li, and G. B. Song, "Recent applications of fiber optic sensors to health monitoring in civil engineering," in Engineering structures, vol. 26, no. 11, pp. 1647-1657, 2004.

[53] J. R. Casas, and P. J. Cruz, "Fiber optic sensors for bridge monitoring," in Journal of Bridge Engineering, vol. 8, no. 6, pp. 362-373, 2004. 
[54] S. Atamturktur, and J. A. Laman, "Finite element model correlation and calibration of historic masonry monuments: a review," in Structural Design of Tall and Special Buildings, vol. 21, no. 2, pp.96-113, 2012.

[55] J. Luo, M. Namburu, K. Pattipati, L. Qiao, M. Kawamoto, and S. A. Chigusa, "Model-based prognostic techniques [maintenance applications]," in Proc. of IEEE Systems Readiness Technology Conference Proceedings, 2003, pp.330-340.

[56] J. Gu, and M. Pecht, "Prognostics and health management using physics-of-failure," in Proceedings of IEEE Reliability and Maintainability Symposium, 2008, pp.481-487.

[57] C. Y. Kim, D. S. Jung, N. S. Kim, and J. G. Yoon, "Effect of vehicle mass on the measured dynamic characteristics of bridges from trafficinduced test," in Proc. IMAC XIX, Kissimmee, FL, 1999, pp. 11061110

[58] C. R. Farrar, and D. A. Jauregui "Comparative study of damage identification algorithms applied to a bridge: I. Experiment," in Smart Materials and Structures, vol. 7, no. 5, 1999.

[59] J. W. Lee, J. D. Kim, C.B. Yun, J.H. Yi, and J.M. Shim, "Healthmonitoring method for bridges under ordinary traffic loadings," in Journal of Sound and Vibration, vol. 257, no. 2, pp. 247-264, 2002.

[60] S. Sun, and L. Sun, (2011) "Video Monitoring on Traffic Flow and Its Integration into SHMS," in the 6th International Workshop on Advanced Smart Materials and Smart Structures Technology.

[61] H. Sohn, "Effects of Environmental and Operational Variability on Structural Health Monitoring," in Philosophical Transactions of the Royal Society, 2006.

[62] Homeland Security Science and Technology, (2010) "Buildings and Infrastructure Protection Series: Bips 01 Aging Infrastructure: Issues, Research, and Technology". Available: http://www.dhs.gov/xlibrary/assets/st-aging-infrastructure-issuesresearch-technology.pdf

[63] R. Zaurin, and F. N. Catbas, "Integration of Computer Imaging and Sensor Data for Structural Health Monitoring of Bridges," in Smart Materials and Structures, vol. 19, no. 1, 2010.

[64] N. Catbas, R. Zaurin, M. Gul, and H. B. Gokce, "Sensor networks, computer imaging, and unit influence lines for structural health monitoring: Case study for bridge load rating" Journal of Bridge Engineering, vol. 17, no. 4, pp. 662-670., 2011.

[65] Y. Chen, C.A. Tan, M.Q. Feng, and Y. Fukuda, "A video assisted approach for structural health monitoring of highway bridges under normal traffic," in Proc. SPIE 6174, Smart Structures and Materials 2006: Sensors and Smart Structures Technologies for Civil, Mechanical, and Aerospace Systems, 61741V, 2006.

[66] I. Darwish, S. J. Cook, M. Garratt, M. Longfield, Z. Hanna, and M. Donoso. (2015) "Infrastructure Monitoring Data Management". Available:

https://www.michigan.gov/documents/mdot/RC1625_499321_7.pdf

[67] G. Fu, and A. G. Moosa, "Structural damage diagnosis using high resolution images" in Structural safety, vol. 23, no. 4, pp. 281-295, 2006.

[68] Basharat, N. Catbas, and M. Shah, "A framework for intelligent sensor network with video camera for structural health monitoring of bridges," in the Proc. of Third IEEE International Conference on Pervasive Computing and Communications Workshops, 2005, pp. 385-389.

[69] K. J. Loh, J. P. Lynch, Y. Wang, K.H. Law, M. Fraser, and A. Elgamal, "Validation of a wireless traffic vibration monitoring system for the Voigt Bridge," in Proceedings of the World Forum on Smart Materials and Smart Structures Technology (SMSST07), Chongqing \& Nanjing, China, 2007, pp. 22-27.

[70] B. Chen, X. Wang, D. Sun, and X. Xie, "Integrated System of Structural Health Monitoring and Intelligent Management for a Cable-Stayed Bridge," in the Scientific World Journal, 2014.

[71] B. Glisic, M. Yarnold, F. Moon, and A.E. Aktan, (2012) "Advanced visualization and accessibility to SHM results involving real-time and historic multi-parameter data and camera images," in Structural Congress, pp. 735-746.

[72] U. Vespier, A. Knobbe, J. Vanschoren, S. Miao, A. Koopman, B, Obladen, and C. Bosma, "Traffic events modeling for structural health monitoring," in Advances in Intelligent Data Analysis X, pp. 376-387, 2011.

[73] S. Dennis, (2009) "Using Pricing to Reduce Traffic Congestion" Available: https://www.cbo.gov/sites/default/files/111th-congress-20092010/reports/03-11-congestionpricing.pdf

[74] M. Chowdhury, A. Sadek, A., Y. Ma, N. Kanhere, and P. Bhavsar, P. "Applications of artificial intelligence paradigms to decision support in real-time traffic management," in Transportation Research Record: Journal of the Transportation Research Board, (1968), pp. 92-98. 2006.

[75] P. Bhavsar, M. Chowdhury, A. Sadek, W. Sarasua, and J. Ogle. "Decision support system for predicting traffic diversion impact across transportation networks using support vector regression". in Journal of Transportation Research Record: Journal of the Transportation Research Board, (2024), pp. 100-106, 2008.

[76] Facts and Statistics - Work Zone Delay, Available: http://www.ops.fhwa.dot.gov/wz/resources/facts_stats/delay.htm

[77] W. Xue, "Integrated transportation monitoring system for both pavement and traffic" Ph.D. dissertation, Virginia Polytechnic Institute and State University, 2013.

[78] L. Wang, W. Xue, C. Druta, and D. Wang, (2012) "Integration of Structural Health Monitoring with Asset Management" Available: http://www.mautc.psu.edu/docs/MAUTC-2009-01\%20VT.pdf

[79] Gonzalez, and R. Karoumi, "Traffic monitoring using a structural health monitoring system," in Proc. of the Institution of Civil Engineers, 2011, pp. 13-23.

[80] M. Fraser, A. Elgamal, X. He, and J.P. Conte, J. P. "Sensor network for structural health monitoring of a highway bridge," in Journal of Computing in Civil Engineering, vol. 24, no. 1, pp. 11-24, 2009.

[81] R. Chang, T. Gandhi, and M.M. Trivedi, "Vision Modules for a MultiSensory Bridge Monitoring Approach," in Proceedings in the 7th International IEEE Conference on Intelligent Transportation Systems, 2004, pp. 971-976.

[82] T. Gandhi, R. Chang, and M.M. Trivedi, "Video and seismic sensorbased structural health monitoring: Framework, algorithms, and implementation," in Intelligent Transportation Systems, IEEE Transactions on Intelligent Transportation Systems, vol. 8, no. 2, pp. 169-180, 2007.

[83] I.Y. Hsu, M. Wódczak, R.G. White, T. Zhang, T., and T.R. Hsing, (2010). "Challenges, approaches, and solutions in intelligent transportation systems," In Second International Conference on Ubiquitous and Future Networks (ICUFN), pp. 366-371.

[84] Guan, S. H. Bayless and R. Neelakantan, "Connected Vehicle Insights Trends in Computer Vision", Available: http://www.its.dot.gov/research/pdf/TechScan\%20computervision\%20I TSA.pdf

[85] Knecht, and L. Manetti, "Using GPS in structural health monitoring," in Proc. of SPIE'S 8th Annual International Symposium on Smart Structures and Materials, 2001, pp. 122-129.

[86] Kim, J.P. Lynch, J.J. Lee, and C.G. Lee, "Truck-based mobile wireless sensor networks for the experimental observation of vehicle-bridge interaction," in Smart Materials and Structures, vol. 20, no. 6, 2011.

[87] Connected Vehicle Reference Implementation Architecture. Available: http://www.iteris.com/cvria/

[88] Connected Vehicle Reference Implementation Architecture Applications, Available: http://www.iteris.com/cvria/html/applications/applications.html

[89] Road Weather and the Connected Vehicle Improving Road Weather Awareness, Available: http://ntl.bts.gov/lib/43000/43500/43531/Connected_vehicle_final.pdf.

[90] K. Dey, A. Mishra, and M. Chowdhury, "Potential of Intelligent Transportation Systems in Mitigating Adverse Weather Impacts to Road Mobility: A Review," in IEEE Transactions on Intelligent Transportation Systems, vol. 16, no. 3, pp 1107-1119, 2015.

[91] R. Murphy, (2011), "Weather and Connected Vehicle" Available: http://www.nritsconference.org/downloads/Presentations11/SessionA2_ Murphy.pdf

[92] R. Bridgelall, "Connected vehicle approach for pavement roughness evaluation" in Journal of Infrastructure Systems, vol. 20, no.1, 2013.

[93] Poursaee, "Automatic corrosion monitoring system for steel reinforcing concrete," in Advances in Engineering Software, vol. 40, pp: 1179-1184, 2011.

[94] Poursaee, "Corrosion measurement techniques in steel reinforced concrete", in Journal of ASTM International (JAI), vol. 8, No 5, 2011.

[95] P.S. Huang, F. Jin, and F.P. Chiang, "Quantitative Evaluation of Corrosion by a Digital Fringe Projection Technique" in Optics And Lasers in Engineering, vol. 31, no. 5, pp. 371-380, 1999.

[96] Poursaee, and C.M. Hansson, "Potential pitfalls in assessing chlorideinduced corrosion of steel in concrete", in Cement and Concrete Research, vol. 39, pp: 391-400, 2009.

[97] A. Knobbe, A. Koopman, J. Kok, B. Obladen, C. Bosma, and E. Koenders, "Large Data Stream Processing for Bridge Management Systems," in Proceedings SMAR. Dubai, 2011. 
[98] K. Lantz, S. Khan, L. B. Ngo, M. Chowdhury, S. Donaher, and A. Apon, "Potentials of Online Media and Location-based Big Data for Urban Transit Networks in Developing Countries," Proceeding of 94th Annual Meeting of the Transportation Research Board, Washington, D.C., 2015.

[99] F. Lécué, S. Tallevi-Diotallevi, J. Hayes, R. Tucker, V. Bicer, M.L. Sbodio, and P. Tommasi, "Star-city: semantic traffic analytics and reasoning for city," in Proceedings of the 19th international conference on Intelligent User Interfaces, ACM, 2014, pp. 179-188.

[100]C. Aggarwal, N. Ashish, and A. Sheth, "The internet of things: A survey from the data-centric perspective" in Managing and mining sensor data, Springer US, pp. 383-428, 2013.

[101]Chodorow, (2013) "MongoDB: the definitive guide" O'Reilly Media, Inc..

[102]M.C. Brown, (2012) "Getting Started with Couchbase Server" O'Reilly Media, Inc.

[103] George, (2011) "HBase: the definitive guide" O'Reilly Media, Inc.

[104] Khetrapal, and V. Ganesh, (2006) "HBase and Hypertable for large scale distributed storage systems" Dept. of Computer Science, Purdue University, Available: http://cloud.pubs.dbs.uni-leipzig.de/node/46

[105] A.M. Middleton, D.A. Bayliss, and G. Halliday, "ECL/HPCC: A Unified Approach to Big Data. In Handbook of Data Intensive Computing" in Springer New York, pp. 59-107, 2011.

[106]E. Hewitt, (2010) "Cassandra: the definitive guide" O'Reilly Media, Inc.

[107]Fuchs, (2012) "Accumulo-Extensions to Google's Bigtable Design".

[108] Stonebraker, and A. Weisberg, "The VoltDB Main Memory DBMS," in IEEE Data Eng. Bull., vol. 36, no. 2, pp. 21-27, 2013.

[109] MySQL: the world's most popular open source database (1995). MySQL $\mathrm{AB}$.

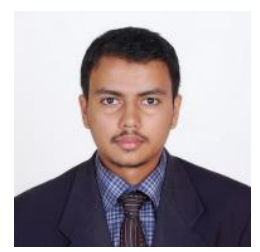

Sakib Mahmud Khan, a Ph.D student at Clemson University, Clemson, SC, USA, received his M.Sc. degree in Civil Engineering from Clemson University, Clemson, SC, USA, in 2015. His research focuses on Intelligent Transportation Systems and Connected Vehicle Technology. Previously he served as a lecturer at the Presidency University in Dhaka, Bangladesh.

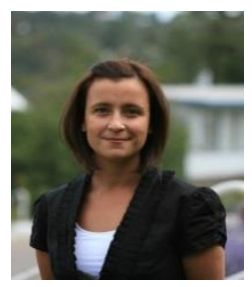

Sez Atamturktur received her Ph.D. degree in Civil Engineering in 2009 from Pennsylvania State University. Currently, an associate professor at Clemson University, she is the director of the CUIdeas research group, which focuses on the development, application and dissemination of model validation and uncertainty quantification techniques. Prior to joining Clemson, Dr. Atamturktur served as a staff member at Los Alamos National Laboratory. Dr. Atamturktur spent the summer of 2013 as an invited by Dr. Scott Cogan visiting professor in the Department of Applied Mechanics at the University of Franche-Comté, France. Dr. Atamturktur serves as the chair of the Model Validation and Uncertainty Quantification Technical Division of the Society of Experimental Mechanics. She serves the principal investigator of a number of federally funded research projects and has published over 50 journal articles on the topics of structural health monitoring, model validation and uncertainty quantification.

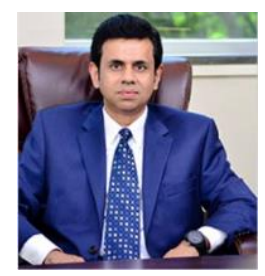

Mashrur Chowdhury is the Eugene Douglas Mays Professor of Transportation in the Glenn Department of Civil Engineering at Clemson University. He is also a professor in the Department of Automotive Engineering at Clemson University and a member of the Clemson University International Center of Automotive Research (CU ICAR). Dr. Chowdhury is a Co-Director of the Complex Systems, Data Analytics and Visualization Institute (CSAVI) at Clemson University. He is the Roadway-Traffic Group lead in the Connected Vehicle Technology Consortium at Clemson University. He is also the Director of the Intelligent Transportation Systems Laboratory at Clemson University. Prior to entering academia in August 2000, he was a Senior ITS Systems Engineer with Iteris Inc. and a Senior Engineer with Bellomo-
McGee Inc., where he served as a Consultant to many state and local agencies, and the U.S. Department of Transportation on ITS related projects. Dr. Chowdhury is a Registered Professional Engineer in Ohio, USA. He is an Associate Editor for the IEEE Transactions on Intelligent Transportation Systems and Journal of Intelligent Transportation Systems. He is a fellow of the American Society of Civil Engineers and a Senior Member of IEEE.

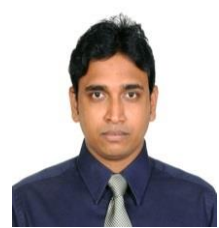

Mizanur Rahman Ph.D. Student in Transportation Systems Engineering at Clemson University, received his M.Sc. degree in civil engineering from Clemson University, Clemson, SC, USA, in 2013. Since 2011, he has been a Research Assistant with Clemson University focusing on data science and Artificial Intelligence (AI) applications for Connected and Automated Vehicle Systems. 